\title{
Setting aside Transactions from Pyramid Schemes as Impeachable Dispositions under South African Insolvency Legislation
}

\section{Z Mabe*}

\section{P.E.R}

Pioneer in peer-reviewed, open access online law publications

Author

Zingapi Mabe

Affiliation

University of South Africa, South Africa

Email mabez@unisa.ac.za

Date published 10 October 2016

Editor Dr A Gildenhuys

How to cite this article

Mabe Z "Setting aside Transactions from Pyramid Schemes as

Impeachable Dispositions under South African Insolvency Legislation" PER / PELJ 2016(19) -

DOI

http://dx.doi.org/10.17159/17273781/2016/v19i0a1236

\section{Copyright}

DOI

http://dx.doi.org/10.17159/1727$3781 / 2016 / v 19 i 0 a 1236$

\begin{abstract}
South African courts have experienced a rise in the number of cases involving schemes that promise a return on investment with interest rates which are considerably above the maximum amount allowed by law, or schemes which promise compensation from the active recruitment of participants. These schemes, which are often referred to as pyramid or Ponzi schemes, are unsustainable operations and give rise to problems in the law of insolvency. Investors in these schemes are often left empty-handed upon the scheme's eventual collapse and insolvency. Investors who received pay-outs from the scheme find themselves in the defence against the trustee's claims for the return of the pay-outs to the insolvent estate. As the schemes are illegal and the pay-outs are often in terms of void agreements, the question arises whether they can be returned to the insolvent estate. A similar situation arose in Griffiths $v$ Janse van Rensburg 2015 ZASCA 158 (26 October 2015). The point of contention in this case was whether the illegality of the business of the scheme was a relevant consideration in determining whether the pay-outs were made in the ordinary course of business of the scheme.
\end{abstract}

This paper discusses pyramid schemes in the context of impeachable dispositions in terms of the Insolvency Act 24 of 1936.

\section{Keywords}

Insolvency law; pyramid schemes; impeachable dispositions; setting transactions aside. 


\section{Introduction}

The South African courts have experienced a steady increase in the number of cases involving schemes that promise a return on investment with interest rates which are considerably above the maximum amount allowed by law, or schemes which promise compensation for the active recruitment of participants. ${ }^{1}$ These schemes, which are often referred to as pyramid or Ponzi ${ }^{2}$ schemes, are unsustainable operations which result in problems in the law of insolvency.

This paper discusses pyramid schemes in the context of impeachable dispositions in terms of the Insolvency Act. $^{3}$ The relevant principles of the law of insolvency will be set out first, followed by a description of the operations of a typical pyramid scheme. The question as to whether or not the law will enforce transactions or contracts emanating from pyramid schemes will then be discussed in the light of recent case law. Lastly, comments will be made on some aspects of these cases.

\section{Some relevant general principles of insolvency law}

The sequestration of the estate of an insolvent person is aimed at equitably distributing his assets among his creditors. ${ }^{4}$ The trustee or liquidator of the insolvent estate is tasked with the duty of collecting, by any possible legal means, all the assets of the estate, in order to benefit the creditors of the estate. ${ }^{5}$ In performing this task, the Act allows a trustee or liquidator to apply to the High Court for an order setting aside dispositions made by a debtor before the sequestration of his estate. ${ }^{6}$

* Zingapi Mabe. LLB (UP), LLM (UP). Lecturer, Department of Mercantile Law, University of South Africa. Email: mabez@unisa.ac.za.

1 See Fourie v Edeling 20054 All SA 393 (SCA) para 1 (hereafter Fourie v Edeling); Moodaley v King 2009 ZANCHC 52 (30 October 2009) (hereafter Moodaley v King); Janse van Rensburg v Botha 2011 ZASCA 72 (25 May 2011) (hereafter Janse van Rensburg v Botha); Gazit Properties v Botha 20122 SA 306 (SCA) (hereafter Gazit Properties v Botha); Janse van Rensburg v Griffiths 20142 All SA 670 (ECP) para 17 (hereafter Janse van Rensburg v Griffiths); Griffiths $v$ Janse van Rensburg 2015 ZASCA 158 (26 October 2015) (hereafter Griffiths $v$ Janse van Rensburg). See generally Woker 2013 SA Merc LJ 237. Hereafter, the male gender will be used as a matter of convenience. It is not meant to discriminate in any way.

2 The word "Ponzi" originates from a Mr Charles Ponzi in the 1920's in Boston, who was known as a swindler because of his money-making scheme that cost investors millions upon the collapse of the scheme. Hereafter, these schemes shall be referred to as pyramid schemes as a matter of convenience.

3 Insolvency Act 24 of 1936 (hereafter the Insolvency Act or the Act).

4 Sharrock, Van der Linde and Smith Hockly's Insolvency Law para 1.2.

5 Sharrock, Van der Linde and Smith Hockly's Insolvency Law 130.

6 See ss 26, 29-31 and 34 of the Insolvency Act. 
The Act defines a disposition as any transfer or abandonment of rights to property and includes a sale, lease, mortgage, pledge, delivery, payment, release, compromise or donation, or a contract for any payment, release, compromise or donation, or a contract for any of these, by the insolvent. ${ }^{7}$

Only the general principles relating to dispositions made not for value ${ }^{8}$ voidable preferences ${ }^{9}$ and undue preferences ${ }^{10}$ will be discussed in this paper. These are the types of dispositions referred to in the case law to be considered here.

\subsection{Dispositions made without value}

Dispositions made without value include those dispositions which the insolvent made before the sequestration of his estate, but for which he did not receive any value in return. ${ }^{11}$ This may happen when an insolvent disposes of his property without receiving adequate compensation or benefit in return, and the disposition results in the sequestration of his estate. $^{12}$

The court may set these dispositions aside under two circumstances: firstly, where the disposition was made more than two years before the date of sequestration of the insolvent's estate, and the trustee can show that directly after the disposition was made, the debtor became insolvent; ${ }^{13}$ and secondly, where the disposition was made within two years of the date of the sequestration of the estate. In the latter case, the court will not set the disposition aside if the person who benefited from the disposition shows that directly after the disposition was made, the debtor's assets exceeded his liabilities. ${ }^{14}$

\section{$2.2 \quad$ Voidable preferences}

Voidable preferences are those dispositions made by an insolvent within six months before the sequestration of his estate, which have the effect of

See s 2 of the Insolvency Act. Also see Meskin et al Insolvency Law para 5.31.2; Bertelsmann et al Mars para 13.3.

See $\mathrm{s} 26$ of the Act.

See $\mathrm{s} 29$ of the Act.

See $\mathrm{s} 30$ of the Act.

11 See s 26 of the Act; Hill v Maria Christ 1927 SWA 50; Estate Wege $v$ Strauss 1932 AD 76 (hereafter Estate Wege $v$ Strauss); Estate Jager $v$ Whittaker 1944 AD 246; Rousseau v Visser 19892 SA 289 (C) 307; Louw v DMA Fishing Enterprises Pty Ltd 20022 SA 163 (SE). See also Bertelsmann et al Mars para 13.2; Sharrock, Van der Linde and Smith Hockly's Insolvency Law para 12.2.1.

12 Bertelsmann et al Mars para 13.2.

13 See s 26(1)(a) of the Act; Bertelsmann et al Mars para 13.2.

14 See s 26(1)(b) of the Act; Bertelsmann et al Mars para 13.2. Sharrock, Van der Linde and Smith Hockly's Insolvency Law para 12.2.1. 
preferring one creditor over another. ${ }^{15}$ Like dispositions made without value, these dispositions can also be set aside if the trustee or liquidator can show that immediately after the disposition was made, the liabilities of the insolvent exceeded his assets. ${ }^{16}$

However, in the case of voidable preferences, if it can be shown that the disposition was made in the ordinary course of the business of the insolvent and it was not intended to prefer one creditor over the others, the disposition will not be set aside. ${ }^{17}$ The creditor in whose favour the disposition was made thus has this defence, which allows him to keep the disposition if he is successful. An objective test is used to determine whether or not the disposition was made in the ordinary course of business. ${ }^{18}$

\subsection{Undue preferences}

An undue preference is a disposition made by the insolvent prior to the sequestration of his estate, with the intention of preferring one creditor over the insolvent's other creditors, and when, at the time of the disposition, his liabilities exceeded his assets. ${ }^{19}$ The test here is subjective, namely whether or not the insolvent intended the disposition to have the effect of preferring one creditor over the others, and whether or not this was the main purpose of making the disposition. ${ }^{20}$

\subsection{Section 33 of the Insolvency Act}

Section 33 provides:

33. Improper disposition does not affect certain rights

(1) A person who, in return for any disposition which is liable to be set aside under section twenty-six, twenty-nine, thirty or thirty-one, has parted with any

15 See $\mathrm{s} 29$ of the Act. Bertelsmann et al Mars para 13.13.

16 See Simon v Coetzee 20072 All SA 110 (T) (hereafter Simon v Coetzee); Estate Hunt $v$ De Villiers 1940 CPD 79 (hereafter Estate Hunt $v$ De Villiers); Bertelsmann et al Mars para 13.13.

17 See S 29 of the Act; Estate Hunt $v$ De Villiers 79; Pretorius' Trustee $v$ Van Blommenstein $1949 \quad 1$ SA 267 (O) (hereafter Pretorius' Trustee $v$ Van Blommenstein).

18 See Hendriks v Swanepoel 19624 SA 338 (A) 345; Amalgamated Banks of South Africa Bpk v De Goede 19974 SA 66 (SCA) 77 (hereafter Amalgamated Banks of South Africa Bpk v De Goede); Simon v Coetzee para 114; Gazit Properties v Botha 309; Bertelsmann et al Mars para 13.17; Sharrock, Van der Linde and Smith Hockly's Insolvency Law para 12.2.2(ii).

19 See s 30 of the Act; Venter $v$ Volkskas Ltd 1973 3 SA 175 (T) 177.

20 Sharrock, Van der Linde and Smith Hockly's Insolvency Law para 12.2.3; Eliasov $v$ Arenel (Pvt) Ltd 19793 SA 415 (R) 418; Pretorius' Trustee v Van Blommenstein; Cooper v Merchant Trade Finance Ltd 20003 SA 1009 (SCA) 1016; Gore v Shell South Africa (Pty) Ltd 20042 SA 521 (C) 530. 
property or security which he held or who has lost any right against another person, shall, if he acted in good faith, not be obliged to restore any property or other benefit received under such disposition, unless the trustee has indemnified him for parting with such property or security or for losing such right.

(2) Section twenty-six, twenty-nine, thirty or thirty-one shall not affect the rights of any person who acquired property in good faith and for value from any person other than a person whose estate was subsequently sequestrated.

This section provides that an investor who received a disposition capable of being set aside as a disposition without value, a voidable preference, or an undue preference, and who parted with property in return for such a disposition, need not return anything he received under the disposition, if he acted in good faith.

The person in whose favour a disposition is made is provided with a defence that he acted in good faith, or a further defence to a claim brought in terms of section 26,29 or 30 to have the disposition set aside. However this defence cannot be raised if the trustee had indemnified the investor for parting with such property.

\subsection{Other relevant legislation}

\subsubsection{Section 11 of the Banks Act}

In terms of the Banks Act, ${ }^{21}$ no person may conduct the business of a bank unless such a person is a public company and is registered as a bank. Therefore, unless a person is a public company and is registered as a bank, that person cannot accept deposits from the general public as an ordinary business practice. The Banks Act makes this conduct illegal and punishable as an offence. ${ }^{22}$

\subsubsection{The Consumer Protection Act}

The Consumer Protection $A_{c t}{ }^{23}$ protects consumers against pyramid schemes and other related schemes by prohibiting people from promoting, knowingly joining, entering into, or participating in multiplication schemes, ${ }^{24}$ pyramid schemes, ${ }^{25}$ chain letter schemes ${ }^{26}$ or any other

21 See s 11(1) of the Banks Act 94 of 1990 (hereafter the Banks Act).

22 See s 11(2) of the Banks Act.

23 See ss 40-46 of the Consumer Protection Act 68 of 2008 (hereafter the CPA) under fair and honest dealings with consumers.

24 Schemes offering interest rates of $20 \%$ and above the South African Reserve Bank regulated REPO rate. See $s$ 43(2)(a) of the CPA.

25 Schemes in which the participants receive compensation primarily from their recruitment of other participants. See s 43(2)(b) of the CPA.

26 Actively soliciting or recruiting participants and obtaining compensation for new recruits. See s 43(2)(c) of the CPA. 
fraudulent schemes or scams. ${ }^{27}$ Prohibited conduct is defined broadly to include an act or omission in contravention of the $\mathrm{CPA}^{28}$ and a party who engages in such conduct may be liable for an administrative penalty imposed by the Tribunal. ${ }^{29}$

\section{The operation of a pyramid scheme}

As already indicated, pyramid schemes are unsustainable and often fraudulent business operations. Although they may attract unsuspecting investors, they also attract greedy investors who want to realise large returns within short periods of time. ${ }^{30}$ These investors are enticed by the promise of short-term returns on investment with interest rates which are considerably higher than average or abnormally inconsistent. ${ }^{31}$

These schemes often do not invest the funds received, but use the money from new investors to pay extravagant returns to earlier investors. ${ }^{32}$ They are usually doomed to collapse because the income made by them is far less than the pay-outs. ${ }^{33}$ As a result, the scheme eventually collapses when the total inflow of funds cannot sustain the outflow of returns allegedly due to the participants. ${ }^{34}$

When these schemes collapse, they are often insolvent. Once a scheme is insolvent, the liquidator or trustee of the insolvent estate collects all the assets of the estate. ${ }^{35}$ To increase the value of the estate, the trustee or liquidator may apply to the High Court to have transactions entered into by the scheme set aside as impeachable dispositions. ${ }^{36}$

The investors who have lost money in the scheme and who are often without legal resources themselves become concurrent creditors ${ }^{37}$ of the

See s 43(2)(d) of the CPA.

See $\mathrm{s} 1$ of the CPA.

29 Tribunal means the National Consumer Tribunal established by s 26 of the National Credit Act 34 of 2005. See s 1 and 112(1) of the CPA.

30 See Paredes-Tarazona v Cobalt Capital (Pty) Ltd 2012 ZAGPJHC 75 (23 April 2012) (hereafter Paredes-Tarazona $v$ Cobalt Capital) para 2.

31 See Paredes-Tarazona v Cobalt Capital para 2. See also Griffiths $v$ Janse van Rensburg para 24, where Gorven AJA held that confident tricksters rely on the twin weaknesses of people, namely greed and gullibility, to attract investors.

32 See Paredes-Tarazona v Cobalt Capital para 2.

33 See Paredes-Tarazona $v$ Cobalt Capital para 2.

34 See Fourie $v$ Edeling para 1. Also see MP Finance Group CC (In Liquidation) $v$ Commissioner, South African Revenue Service 20075 SA 521 (SCA) 521.

35 See s 20(1) of the Act.

36 See generally ss $26-31$ of the Act.

37 Concurrent creditors are creditors who have not secured preferent claims against the estate, and they are paid out of the free residue after any preferent creditors have been paid. They therefore do not enjoy any advantage over other creditors of the estate of the insolvent. See Bertelsmann et al Mars para 22.13. 
insolvent estate. In addition, the investors who deposited money into the scheme and took their gains without re-investing these funds are often left trying to defend applications made to the High Court for the return of their investment to the insolvent estate.

\section{Case law}

The question as to whether or not the law will enforce transactions or contracts emanating from pyramid schemes will now be discussed in the light of recent case law.

A number of Supreme Court of Appeal cases in South Africa have followed a certain approach to determine whether transactions concluded by illegal and insolvent pyramid schemes should be set aside, where there is a defence by an investor that a contract was concluded in the ordinary course of business of the scheme, in the context of section 29 of the Act.

This approach considers all the facts of the case and has, until recently, ${ }^{38}$ never been questioned with regard to its being the custom in such cases. ${ }^{39}$ As this approach considers all the facts of a case, it is referred to as the broad approach.

The cases that follow demonstrate how the courts have used this broad approach in an attempt to provide a just result for an investor who is deceived into investing money in a pyramid scheme and is left emptyhanded after its collapse and insolvency.

\subsection{The broad approach}

\subsubsection{Fourie $v$ Edeling}

This case was an appeal against orders in terms of section 26 and 30 of the Insolvency Act by Hartzenberg J.40 Hartzenberg $\mathrm{J}$ had ruled that the Krion Pyramid Investment Scheme ${ }^{41}$ was insolvent, and that the contracts

38 See Janse van Rensburg $v$ Griffiths para 25, where it was argued on behalf of the defendant that the Supreme Court of Appeal in Gazit Properties $v$ Botha revisited the broad approach. Brooks AJ in para 27 of this case rejected this contention.

39 See Janse van Rensburg $v$ Griffiths para 17, where Brooks AJ explains that the wide approach principle was applied consistently by the Supreme Court of Appeal for almost a hundred years, when the Supreme Court of Appeal was still known as the Appellate Division. Also see Griffiths $v$ Janse van Rensburg, which restated and applied this principle.

$40 \quad$ See Fourie $v$ Edeling para 4.

41 This scheme was conducted in a manner that attracted "investors to invest for periods as short as three months. When the loan capital with 'interest' was repaid at the end of the agreed investment period, the investor would more often than not reinvest the capital and interest. The advantage for the investor of doing business in this way was of course that his already enormous interest was compounded. 
it concluded with investors were illegal and therefore null and void. ${ }^{42}$ Consequently, all actual payments by the scheme from March 1999 were set aside as dispositions, because they were made at a time when the scheme was insolvent. The dispositions were held to have been made with the intention of preferring one investor over the others in terms of section 30 of the Insolvency Act. ${ }^{43}$

The words "all actual payments" and the reasons provided by Hartzenberg $\mathrm{J}$ gave rise to interpretational problems. ${ }^{44}$ It was not clear from the order whether this meant that all payments to investors, including capital repayments, were set aside, or only the gains of each investor. ${ }^{45}$

Conradie JA clarified Hartzenberg J's order that only the gains of each investor were set aside because they were illegal. ${ }^{46} \mathrm{He}$ disagreed, however, with the order's being made under section 30 of the Insolvency Act. ${ }^{47}$ Instead, he held that the order could have been made in terms of section 26, which refers to dispositions without value. ${ }^{48} \mathrm{He}$ said that a disposition was not made for value if the payment of returns was illegal. ${ }^{49}$ A promise to pay returns on payments that were illegal is null, and any payment in this regard would be a disposition not made for value..$^{50}$ If a repayment with a book entry did not qualify as a disposition, a pay-out of profits retained by the scheme was also not a disposition. ${ }^{51}$ Only the actual payment of the accrued gains would be a disposition without value. ${ }^{52}$

It was accepted by the parties before the court that the repayment of an investor's capital was not a disposition without value, and therefore could not be set aside as such. ${ }^{53}$ This was because the investor's condictio ${ }^{54}$

Typically an investor would invest an amount in the scheme having been promised a return of $10 \%$ per month, capital and profit repayable within three months. Until the collapse of the scheme, investors received repayment of their capital and their profit when due. Sometimes an investor would leave the capital and/or the profit in the scheme and this would then have been reflected by means of a book entry as a payment and a new investment. Other investors would take their capital and profit on the due date, some of whom returned after a while to reinvest a similar amount." See Fourie $v$ Edeling para 1.

42 See Fourie $v$ Edeling para 4.

43 See Fourie $v$ Edeling para 4.

44 See Fourie $v$ Edeling para 5.

45 See Fourie $v$ Edeling para 5.

$46 \quad$ See Fourie $v$ Edeling para 16.

47 See Fourie $v$ Edeling para 16.

48 See Fourie $v$ Edeling para 17.

49 See Fourie $v$ Edeling para 18.

50 See Fourie $v$ Edeling para 19.

51 See Fourie $v$ Edeling para 19.

52 See Fourie $v$ Edeling para 19.

53 See Fourie v Edeling para 19. 
prevented it from taking on this character. The disposition was made to discharge the responsibility to return the illegal payment. ${ }^{55}$

Conradie JA therefore ordered that only actual payments, whether profit or interest, in so far as they exceed the investment of each particular investor, be set aside as dispositions without value. ${ }^{56}$ This was under the condition that the right of the investor to rely on section 33 of the Insolvency Act was not affected by the order. ${ }^{57}$ In this regard Conradie JA held that the court a quo preserved the right in section 33 in its order. ${ }^{58}$ As a result, the capital repayments by the illegal scheme to the investor could not be set aside as dispositions without value.

\subsubsection{Moodaley v King}

Another example of a case where the court appeared to have ruled in favour of an investor who participated in a pyramid scheme and where the court applied Fourie $v$ Edeling is Moodaley $v$ King. In this case Mr Moodaley, who was a dentist, his wife, who was a business woman, and his son, who was an accountant, invested money in a pyramid scheme operated by Mr King. When the scheme collapsed they were left emptyhanded and applied to the High Court for an order against Mr King for the repayment of their capital investments and interest.

Kgomo JP ordered Mr King to repay the capital amounts that the Moodaleys had invested, but refused to grant judgment for the exorbitant (and illegal) interest that had been promised by the scheme. ${ }^{59} \mathrm{Kgomo} \mathrm{JP}$ relied on the principle in Fourie $v$ Edeling ${ }^{60}$ that a disposition was not made for value if the payment was illegal. ${ }^{61} \mathrm{~A}$ promise to pay returns on payments that were illegal is null, and any payment in this regard would be a disposition not made for value. ${ }^{62}$ If a repayment with a book entry did not qualify as a disposition, a pay-out of profits retained by the scheme was

54 The condictio ob turpem vel iniustam causam (hereafter condictio) is an unjustified enrichment claim based on the fact that the amount claimed was transferred pursuant to an agreement that is void and unenforceable because it is illegal. See in this regard Afrisure $v$ Watson 2008 ZASCA 89 (11 September 2008); First National Bank of Southern Africa Ltd v Perry 20013 SA 960 (SCA) para 22; Visser Unjustified Enrichment 425.

55 See Fourie $v$ Edeling para 19.

56 See Fourie $v$ Edeling para 20.

57 In terms of $s 26$ of the Act. See Fourie $v$ Edeling para 20.

58 See Fourie $v$ Edeling para 20.

59 See Moodaley $v$ King paras 12-13.

60 See Fourie $v$ Edeling para 19. Also see the discussion on Fourie $v$ Edeling in para 4.1.1 of this contribution.

61 See Fourie $v$ Edeling para 18.

62 See Fourie $v$ Edeling para 19. 
also not a disposition. ${ }^{63}$ Only the actual payment of the accrued gains would be a disposition without value. ${ }^{64}$

\subsubsection{Janse van Rensburg v Botha}

In Janse van Rensburg $v$ Botha, the court had to determine whether or not the Krion Pyramid Scheme, which later became insolvent, was a debtor for the purposes of setting aside transactions it concluded in terms of section 29 of the Act. ${ }^{65}$

The scheme had made certain dispositions to Mr Botha, who had invested in the scheme. The liquidators of the estate applied to set these dispositions aside in terms of section 29 of the Act. ${ }^{66}$ In an attempt to defend the application and the consequent order to repay the disposition into the insolvent estate, Mr Botha alleged, among other things, that because the scheme was unlawful and all obligations incurred or undertaken were void, the scheme could not be a debtor for the purposes of setting aside its transactions in terms of section 29 of the Act. ${ }^{67}$

In this regard Heher JA held that illegal acts between the parties have no legal consequences. ${ }^{68}$ However, this does not mean that because an agreement is illegal a court will ignore or deny its conclusion and existence. ${ }^{69}$ The conclusion of an illegal agreement allows the law to recognise the agreement for particular purposes. The fact that the agreements between the parties were void did not take away the legal consequences. ${ }^{70}$

Thus, Heher JA said that the illegality of the scheme did not deprive it of debtor status. ${ }^{71}$ Section 29 was created to assist in the administration of an insolvent estate, and to recover assets disposed of by the insolvent for the benefit of creditors. ${ }^{72}$ It is remedial in nature and should not hinder the process. $^{73}$

Furthermore, if an insolvent is regarded as a debtor, the illegality of the insolvent's business should not influence a liquidator's right to utilise

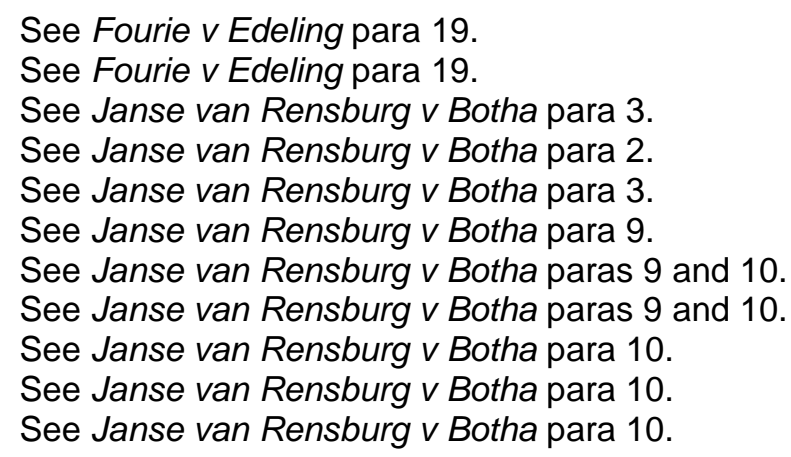


section 29. ${ }^{74}$ For a proper conclusion in terms of the circumstances of this case, the court held that the illegality of the insolvent's business should be disregarded when interpreting section $29 .{ }^{75}$ In this respect, disregarding the illegality of the business would not result in the upholding of an illegal contract. ${ }^{76}$ Heher JA therefore held that the scheme was a debtor for purposes of section 29 in respect of any dispositions that it made to investors by repayment of capital or interest arising from the operation of the scheme. ${ }^{77}$

\subsection{The narrow approach}

The following cases will demonstrate how the courts deal with the question regarding whether or not payments made with regard to illegal pyramid schemes qualify as payments made in the ordinary course of business in terms of section 29 of the Act. In this regard the Supreme Court of Appeal has always applied the broad approach. However, the Supreme Court of Appeal, in the recent case of Gazit Properties $v$ Botha, appears to have departed from this approach and taken a more narrow approach to the investigation.

\subsubsection{Gazit Properties v Botha}

This was an appeal against an order made in terms of section 29 of the Act, setting aside dispositions made by Malokiba ${ }^{78}$ to Gazit. ${ }^{79}$ Malokiba operated a pyramid scheme which later became insolvent. ${ }^{80}$ The inevitable happened and the entire scheme collapsed when the new investors' funds used to pay out earlier investors were insufficient. ${ }^{81}$

Gazit, an investor in the scheme, loaned an amount of R5 million to Malokiba in terms of written loan agreements. ${ }^{82}$ Gazit would receive interest on the capital loan on a monthly basis, and the agreements would continue for an indefinite period, subject to cancellation. Gazit cancelled the loan agreements and the full capital and interest were paid by

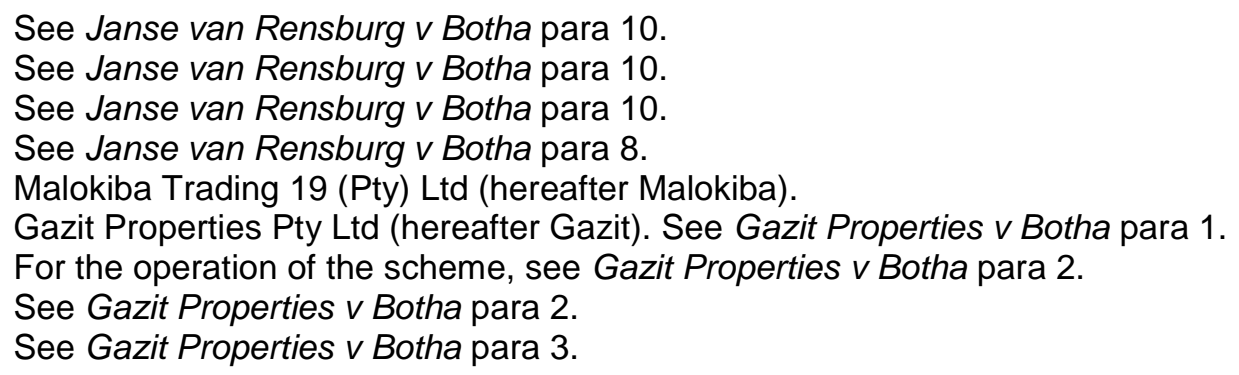


Malokiba. ${ }^{83}$ Majiedt JA had to determine whether or not these payments to Gazit were made in the ordinary course of business. ${ }^{84}$

Gazit argued that Malokiba repaid the loans in accordance with his obligations in terms of a valid loan agreement in the ordinary course of business. ${ }^{85}$ The liquidators argued that this was not true because the business was tainted, and the loan agreements could not be regarded as genuine loans. ${ }^{86}$ They based their contentions on the contravention of the Banks Act, ${ }^{87}$ the excessiveness of the interest paid, and the fact that the business constituted a prohibited pyramid scheme. 88 However, the liquidators subsequently abandoned the last two arguments, and the focus was solely on the contravention of the Banks Act.

Majiedt JA held that the High Court had placed too much emphasis on the tainted nature of the transactions whereby Malokiba repaid the loans to Gazit. ${ }^{89}$ Such contamination was found by the High Court to have been caused by the violation of the Banks Act and the conclusion of agreements under false pretences. Majiedt JA said that the focus should not be on the nature of the insolvent's general business practices. Instead, the disposition should itself be scrutinised, taking into account its cause. ${ }^{90}$

Majiedt JA referred to Estate Wege $v$ Strauss. ${ }^{91}$ It was held in that case that if a debtor paid a debt in terms of his contract, such a payment would have been made in the ordinary course of business. ${ }^{92}$ Majiedt JA interpreted this to mean that one first has to consider the nature of the obligation in terms of which the disposition was made. ${ }^{93}$

Majiedt JA reasoned that based on the uncontested facts and admissions by Gazit, the loans had been repaid by Malokiba in terms of the provisions of the parties' loan agreements. ${ }^{94}$ This was simply a loan agreement whereby one party lends money to another, and the latter agrees to return the money with interest at a certain time.${ }^{95}$ As Gazit had a contractual right

\footnotetext{
See Gazit Properties v Botha para 3.

See Gazit Properties v Botha para 4.

See Gazit Properties v Botha para 5.

See Gazit Properties $v$ Botha paras 5 and 6.

See s 11(1) of the Banks Act.

See Gazit Properties v Botha para 5.

See Gazit Properties v Botha para 7.

See Gazit Properties v Botha para 7.

See Gazit Properties v Botha para 8.

See Gazit Properties v Botha para 8.

See Gazit Properties v Botha para 8.

See Gazit Properties v Botha para 9.

See Gazit Properties v Botha para 9.
} 
to be repaid upon cancellation, Malokiba had a reciprocal obligation to make repayment. ${ }^{96}$

Majiedt JA held that the fact that there was a violation of the Banks Act did not mean that the loan agreements were not standard loan agreements. ${ }^{97}$ He further stated that there was no evidence indicating that Gazit knew that Malokiba's business was illegal. ${ }^{98}$

Majiedt JA also distinguished the circumstances of this case from those of Janse van Rensburg $v$ Botha. Although in both cases there was an application in terms of section 29, a disposition in the ordinary course of business was not one of the issues in Janse van Rensburg $v$ Botha. ${ }^{99}$ Majiedt JA therefore found that the High Court erred in upholding the liquidators' claim in terms of section 29(1) of the Act. ${ }^{100}$

\subsubsection{Janse van Rensburg v Griffiths}

In this case Brooks AJ was faced with the same question as in Gazit Properties $v$ Botha, namely whether or not payments made in terms of an illegal pyramid scheme qualified as payments made in the ordinary course of business. The case involved a pyramid scheme that had been conducted through the Usapho Trust (Trust), and which was sequestrated on 14 September 2000. ${ }^{101}$

Mr Griffiths, an investor and creditor of the scheme, made substantial payments to the scheme. ${ }^{102}$ The first payment, an amount of R100 000, was transferred as capital by Mr Griffiths to the Trust on 15 December 1999. ${ }^{103}$ This amount was to be repaid by the Trust on 23 March 2000. As repayment, the Trust deposited the capital amount of R100 000 on 27 March 2000 into Mr Griffiths' bond account. ${ }^{104}$ As interest on this capital amount, Mr Griffiths received an amount of R12 000 from the Trust on or about 27 March 2000. ${ }^{105}$

The second capital payment, an amount of R100 000, was transferred by Mr Griffiths to the Trust on 6 April 2000. As per their agreement, on 3 June

\footnotetext{
96 See Gazit Properties v Botha para 9.

97 See Gazit Properties v Botha para 10; Amalgamated Banks of South Africa Bpk v De Goede para 97A-D.

98 See Gazit Properties v Botha para 11.

99 See Gazit Properties v Botha para 14. Also see Janse van Rensburg v Botha para 3.

100 See Gazit Properties $v$ Botha para 15. Also see the discussion of Janse van Rensburg $v$ Botha in para 4.1.3 of this contribution.

101 See Janse van Rensburg v Griffiths para 1.

102 See Janse van Rensburg $v$ Griffiths para 2.

103 See Janse van Rensburg $v$ Griffiths para 12.3.1.

104 See Janse van Rensburg $v$ Griffiths para 12.3.1.

105 See Janse van Rensburg v Griffiths para 6.3.
} 
2000 the capital sum of R100 000 was then deposited back into Mr Griffiths' bond account by the Trust. ${ }^{106}$ Again on 3 June $2000 \mathrm{Mr}$ Griffiths received interests in the amount of R12 000 on the capital amount. ${ }^{107}$

In total, four separate payments were made by the Trust to Mr Griffiths; two capital payments and two interest payments. The plaintiffs sought an amount of R224 000 in total as payment for each of the four payments made to $\mathrm{Mr}$ Griffiths, and the interest on those payments. ${ }^{108}$

The plaintiffs firstly based their claims on section 26 of the Act, but concentrated on the alternative claim based on section 29 of the Act. ${ }^{109} \mathrm{Mr}$ Griffiths claimed that the repayments had been made in the ordinary course of business. The Trust was obliged to repay all the capital amounts because they were paid in terms of their loan agreement. ${ }^{110}$

Brooks AJ stated that an objective test is used to determine whether or not a disposition is made in the ordinary course of business. ${ }^{111}$ The terms of the transaction and all the circumstances under which it was entered into need to be considered. ${ }^{112}$ Essentially, the question is whether or not it could be said that it is normal for solvent business people to conclude such transactions. ${ }^{113}$

He explained that this approach has been consistently applied by judgments coming from the Supreme Court of Appeal for a long time. ${ }^{114}$ He referred to Fourie $v$ Edeling, where Conradie JA held that investments in a pyramid scheme are illegal and therefore void. ${ }^{115}$ Brooks AJ applied the view in Fourie $v$ Edeling that a disposition made in the ordinary course of a business means a "lawful" disposition made in the ordinary course of a "lawful" business. ${ }^{116}$

Brooks AJ rejected the viewpoint that the Supreme Court of Appeal in Gazit Properties v Botha revisited the objective approach. ${ }^{117}$ He disagreed with the submission that Gazit Properties $v$ Botha departed from the

\footnotetext{
106 See Janse van Rensburg v Griffiths paras 12.3.3-12.3.4.

107 See Janse van Rensburg $v$ Griffiths para 6.3.

108 See Janse van Rensburg v Griffiths para 2.

109 See Janse van Rensburg $v$ Griffiths paras 3-4.

110 See Janse van Rensburg v Griffiths para 3.

111 See Janse van Rensburg $v$ Griffiths para 16.

112 See Janse van Rensburg $v$ Griffiths para 16.

113 See Janse van Rensburg $v$ Griffiths para 16.

114 See Janse van Rensburg $v$ Griffiths para 17.

115 See Janse van Rensburg $v$ Griffiths para 20. Also see the discussion of Fourie $v$ Edeling in para 4.1.1 of this contribution.

116 See Janse van Rensburg $v$ Griffiths para 23.

117 See Janse van Rensburg $v$ Griffiths para 24.
} 
principles set out in the Supreme Court of Appeal judgments. ${ }^{118}$ In his view the source of the investigation in that case was much narrower than the facts in the other cases before the Supreme Court of Appeal. ${ }^{119}$

He adopted the view that the complaint in Gazit Properties that the disposition had not been made in the ordinary course of business was restricted to two narrow issues: the alleged contravention of the Banks $A c t$, and the allegation that investors entered into the transactions under false pretences. ${ }^{120}$ Brooks AJ failed to understand the court's conclusion, namely that the manner in which the investors were misled was fraudulent. ${ }^{121} \mathrm{He}$ regarded the basis of the liquidators' complaints to be limited, and not to extend to the disposition having been made to Gazit Properties as part of an illegal pyramid scheme. He regarded this as the distinguishing factor between the factual circumstances of each of the two cases. ${ }^{122}$

Brooks AJ found it unlikely that what Majiedt JA meant by saying "what is required is a close scrutiny of the disposition itself [sic], viewed against the background of its [sic] causa" was intended to restate and express the objective test differently. ${ }^{123} \mathrm{He}$ took the standpoint that Majiedt JA had recognised the relevance of the broad approach and endorsed the nature of the enquiry. ${ }^{124}$ The finding in Gazit Properties $v$ Botha that the disposition was made in the ordinary course of business must be limited to the facts of that case, where the broad approach remained intact. ${ }^{125}$

Brooks AJ concluded that the dispositions made to Mr Griffiths could not be said to have been made in the ordinary course of the business of the Trust. ${ }^{126}$ The illegality of the business operations, the manner in which participation in the scheme was secured, and the exorbitant returns on the investment contributed to such a conclusion. ${ }^{127}$ The court accordingly ordered the four payments, which consisted of the two capital payments and the two interest payments, to be set aside as voidable preferences under section 29 of the Insolvency Act. ${ }^{128} \mathrm{Mr}$ Griffiths was therefore ordered to pay R224 000.

\footnotetext{
See Janse van Rensburg v Griffiths para 27.

See Janse van Rensburg v Griffiths para 27.

See Janse van Rensburg v Griffiths para 27.4.

See Janse van Rensburg $v$ Griffiths para 27.4.

See Janse van Rensburg v Griffiths para 27.4.

See Janse van Rensburg $v$ Griffiths para 28.

See Janse van Rensburg $v$ Griffiths para 28.

See Janse van Rensburg $v$ Griffiths para 30.

See Janse van Rensburg $v$ Griffiths para 31.

See Janse van Rensburg $v$ Griffiths para 31.

See Janse van Rensburg v Griffiths paras 34, 37.
} 


\subsubsection{Griffiths v Janse van Rensburg}

This case was an appeal arising from the above judgment by Brooks AJ in Janse van Rensburg $v$ Griffiths, which set aside both capital and interest payments as voidable dispositions. In this appeal it was conceded by the parties that the two amounts of R12 000 representing interest were not made in the ordinary course of business, and Mr Griffiths accordingly agreed to an order to have them set aside. ${ }^{129}$ The issue in this appeal was therefore whether or not Mr Griffiths had proved that the two capital dispositions were made in the ordinary course of business. ${ }^{130}$

Gorven AJA restated and applied the objective test that in determining whether or not a disposition had been made in the ordinary course of business, the disposition should be evaluated in light of all relevant facts. ${ }^{131}$ Gorven AJA also restated the question to be answered, namely whether or not it is normal for ordinary, solvent business people to conclude transactions as did the parties in this case, in similar circumstances. ${ }^{132}$

He agreed with Brooks AJ that Gazit Properties v Botha applied the wellknown broad test, but disagreed with the suggestion that the test had been narrowed. ${ }^{133}$

He also agreed that the investment agreements in the present case were illegal and void, whereas the loan agreement in Gazit Properties v Botha was valid and enforceable. ${ }^{134} \mathrm{He}$ further held that the dispositions in this case were certainly not made in the ordinary course of business. ${ }^{135}$ However, he was of the view that Brooks AJ's finding based on the dictum ${ }^{136}$ that it must be a lawful or valid disposition made in the ordinary course of a lawful business went too far. ${ }^{137}$

He referred to the statements by Brooks AJA that ordinary, solvent business people do not enter into unlawful agreements or attempt to obtain unlawful dispositions. ${ }^{138}$ However, Gorven AJA indicated that this cannot be said in respect of the requirement that the disposition must be

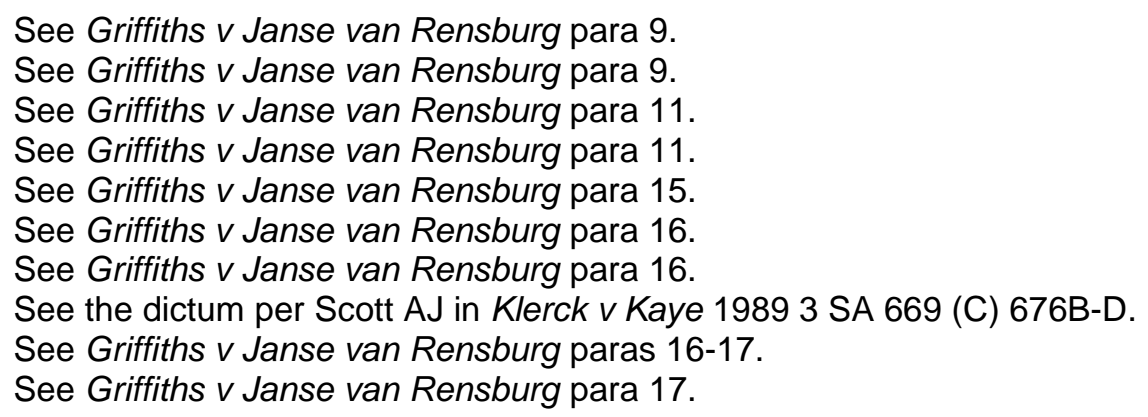


made in the course of a lawful business. ${ }^{139}$ Gorven AJA gave the example of a Trust leasing premises and concluding agreements with a municipality to render services. ${ }^{140}$ In such a case, payments to the municipality and rent to the landlord would not be set aside as not having been made in the ordinary course of business. ${ }^{141}$

He held that the abovementioned dictum ignored the nature of the business relationship between the insolvent and the recipient at the time that the disposition was made. ${ }^{142}$ As a result, attention shifted to the general nature of the business, as opposed to the business relationship between the insolvent and the recipient. ${ }^{143}$ Therefore in Gazit Properties v Botha the business operations contravened the Banks Act, but the relationship between the parties was concluded in terms of an enforceable loan agreement. ${ }^{144}$

Gorven AJA accordingly held that Brooks AJ erred in applying the dictum, because he failed to focus on the relationship between Mr Griffiths and the Trust. ${ }^{145}$ As a result, the basis on which Mr Griffiths relied in his claim to retain the two capital dispositions was misinterpreted. ${ }^{146} \mathrm{He}$ agreed that the agreements were illegal and void, as per Fourie $v$ Edeling. However, the claim for repayments should have been based on the condictio ob turpem vel iniustam causam ${ }^{147}$ for the immediate repayment of the two capital sums. ${ }^{148}$ The court therefore had to determine whether or not a payment under the condictio qualified as one which was made in the ordinary course of business. ${ }^{149}$ In this regard, Gorven AJA said that had Mr Griffiths made claims in terms of the condictio, he would have been successful. The dispositions would then have derived from lawful and enforceable obligations. ${ }^{150}$

Gorven AJA reiterated that Mr Griffiths should have focused on the dispositions themselves. ${ }^{151} \mathrm{Mr}$ Griffiths did not raise the condictio because

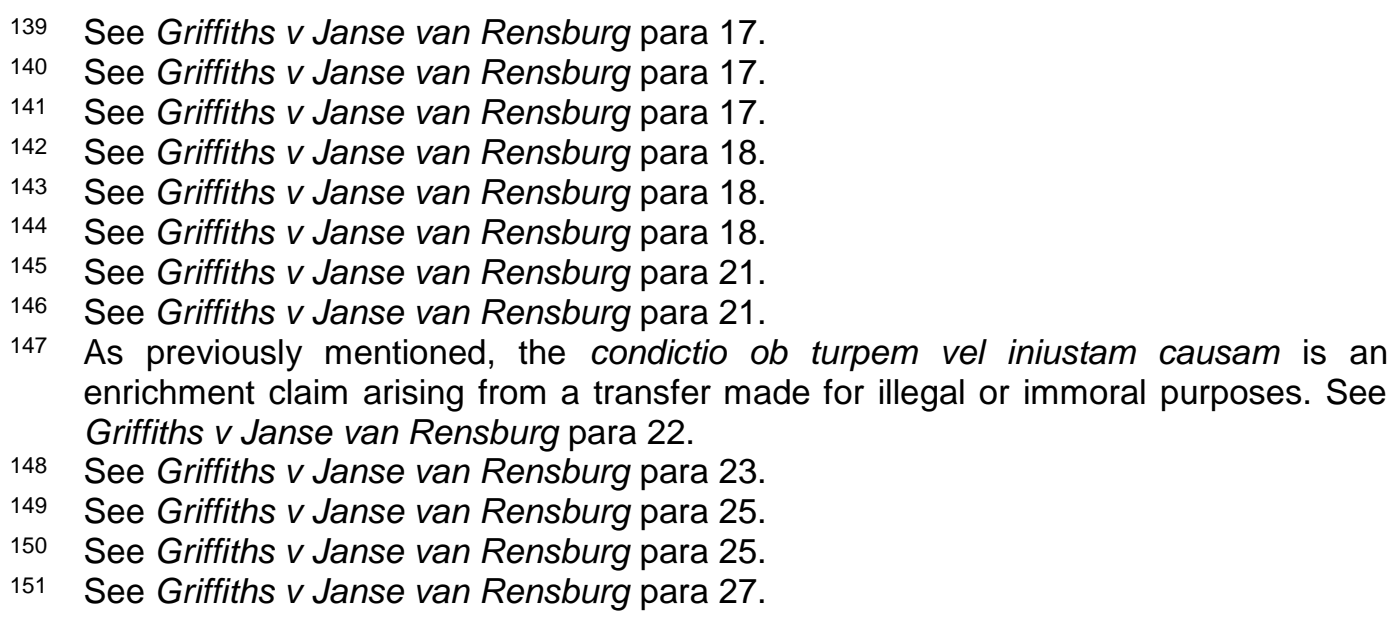

148 See Griffiths v Janse van Rensburg para 23.

149 See Griffiths v Janse van Rensburg para 25.

150 See Griffiths v Janse van Rensburg para 25.

151 See Griffiths $v$ Janse van Rensburg para 27. 
he was unaware that he had a valid claim under the condictio. ${ }^{152}$ If he had been aware of this and demanded payment of the capital under the condictio, his relationship with the Trust would have arisen from the condictio. ${ }^{153}$ Unfortunately, in this case, the business relationship between the parties arose from the void agreements and not from the condictio. ${ }^{154}$

Gorven AJA emphasised that the test to determine whether dispositions were made in the ordinary course of business in terms of section 29 of the Act is still objective. It considers whether at the time, and under the circumstances in which the dispositions were made, they gave effect to a valid underlying causa. ${ }^{155}$ In this case the payments were made in accordance with the terms of the investment agreements. ${ }^{156}$ The dispositions must therefore be treated in the same way as the interest payments, because they were part of the same transactions. ${ }^{157}$ Gorven AJA accordingly confirmed the decision of the High Court that the capital repayments had not been made in the ordinary course of business, and were therefore correctly set aside. ${ }^{158}$

\section{Commentary}

When a debtor in insolvency proceedings is a pyramid scheme, the illegality of the scheme gives rise to problems. The common problem that is evident from the cases that have been discussed above relates to the impeaching of the transactions of the pyramid scheme. As the facts of each case differ, the courts have to scrutinise each case to determine whether or not a disposition can be set aside as an impeachable disposition, and if so, to what extent.

As indicated, section 33 of the Insolvency Act provides that an investor need not restore anything received under a disposition if he can show that he acted in good faith. Section 33 therefore provides an investor who is ordered to return a disposition made by an insolvent debtor with a defence against such an order.

However, proving that an investor acted in good faith could be difficult. This is because there are those investors who, genuinely and out of ignorance, do not know that the scheme is fraudulent and invest money, consequently losing some or all of their investments. There are also those

\footnotetext{
See Griffiths v Janse van Rensburg para 28.

See Griffiths v Janse van Rensburg para 29.

See Griffiths v Janse van Rensburg para 29.

See Griffiths v Janse van Rensburg para 30.

See Griffiths $v$ Janse van Rensburg para 30.

See Griffiths v Janse van Rensburg para 30.

See Griffiths $v$ Janse van Rensburg para 31.
} 
smart investors who are aware of the illegality of the scheme, but intend to use the scheme to make quick money. These investors advance money into the scheme, receive the illegally promised profits, and do not reinvest the money back into the scheme.

The former investors seem to be the most disadvantaged by pyramid schemes, as they may have received little or no profit from their investment. They become concurrent creditors of the insolvent estate and, because they might not have received any repayments from the scheme, section 33 appears not to apply to them. This is because section 33 indicates that the investor must have received a disposition that is capable of being set aside as a disposition without value.

On the other hand, the latter investors appear to be the least disadvantaged by the scheme. This is because they received repayments from the scheme. Although they may be required to pay back the money, they can still rely on section 33, provided that they can show good faith.

However neither section 33 nor the courts indicate the factors that must be presented to show that the parties acted in good faith in such circumstances. Neither section 33 nor the courts indicate whether, if the investor succeeds in showing good faith, he will be required to repay only the illegal gains, or if he will be entitled to keep the capital repayments, together with the illegal gains.

In Fourie $v$ Edeling Conradie JA did not comment on whether or not the investor acted in good faith, and preferred just to mention that his ruling should not in any way affect the investor's right to rely on section 33.

In Moodaley $v$ King Kgomo JP appears to have made a just judgment in applying Conradie JA's judgement in Fourie $v$ Edeling. The outcome avoided the situation where the court refused to assist the Moodaleys because they had participated in an illegal scheme, thereby leaving Mr King, the originator of the scheme, in possession of the illegal profit. The court also avoided enforcing an illegal arrangement by refusing to order $\mathrm{Mr}$ King to pay the Moodaleys what had been promised by the scheme. However Kgomo JP's comment that the Moodaleys were:

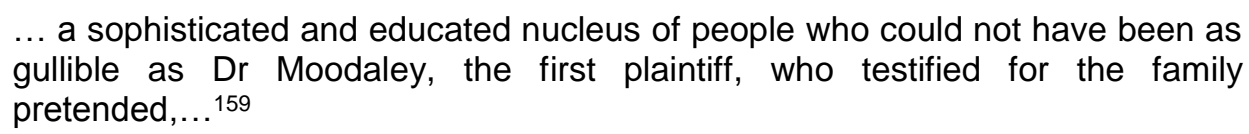

gives the impression that he was not convinced that the Moodaleys acted in good faith. 
From the above discussion it is clear that pyramid schemes are illegal and that the courts will not enforce agreements emanating from them, or at least will not enforce the illegal part of the agreement. However, the law is not always so just to investors or participants of pyramid schemes when the estate of the originator of the scheme is sequestrated. Upon the sequestration of the estate of a debtor, all the assets of his estate vest in the trustee of the insolvent estate. ${ }^{160}$ The trustee acts in the best interests of the creditors of the estate and may apply to the High Court for an order setting aside transactions concluded by the insolvent with investors. Should the court grant these orders, the investor may have to pay to the insolvent estate the money that was paid by the insolvent estate to the investor as a return on the investment. ${ }^{161}$

This outcome was seen in Janse van Rensburg $v$ Botha, where Heher JA held that just because the scheme was illegal, this did not mean that the agreements which it concluded did not have legal consequences. Seeking to give effect to section 29 of the Act, Heher JA disregarded the illegality of the agreements entered into by the illegal scheme. He held that for the purposes of the dispositions made by the scheme, the scheme is a debtor and should incur the legal consequences of a debtor. In this respect, the legal consequences were to set aside the disposition and claim the money back for the creditors of the insolvent estate.

The challenge arises, however, when an investor decides to rely on one of the defences against the setting aside of dispositions. Such a defence would include that in section 29 of the Act, one element of which is that the disposition was made in the ordinary course of business. As already indicated, the objective approach is followed by the courts to determine if the disposition was indeed made in the ordinary course of business.

Although the appeal court in Griffiths $v$ Janse van Rensburg restated the objective approach, the judgment did not clear up the inconsistency brought about by Gazit Properties $v$ Botha; instead, the appeal court created further uncertainty about what the objective approach entails. In both Gazit Properties $v$ Botha and Janse van Rensburg $v$ Griffiths, it was clear that all the facts of a case have to be considered. Gorven AJA in Griffiths $v$ Janse van Rensburg criticised the long-standing dictum ${ }^{162}$ for

160 See s 20(1) of the Insolvency Act; Sharrock, Van der Linde and Smith Hockly's Insolvency Law para 5.1.

161 See s 32(3) of the Insolvency Act.

162 That the disposition must have been a lawful disposition made in terms of a lawful business. 
overlooking the nature of the relationship between the parties and focusing solely on the general nature of the business.

Although he based his finding on different reasons, Gorven AJA reached a finding similar to the one in Gazit Properties $v$ Botha, namely that $\mathrm{Mr}$ Griffiths should have focused on the disposition itself and not on the nature of the business. He held that the focus should have been on whether or not the agreement that gave rise to the disposition was a legal and enforceable contract. In his explanation he separated the lawfulness of the agreement that gave rise to the disposition from the lawfulness of the business itself. He said that the focus should be on the nature of the business relationship between the parties, and not on the general nature of the business.

He stated that solvent business people do not conclude unlawful agreements. Furthermore, he held that in Gazit Properties $v$ Botha, even though the business itself was unlawful, the relationship between the parties was created by an enforceable loan contract. In contrast, in Griffiths $v$ Janse van Rensburg the agreements themselves were illegal and void. Therefore, the relationship between the parties was created by already illegal and void agreements. Gorven AJA indicated that $\mathrm{Mr}$ Griffiths should have claimed repayment in terms of the condictio and not in terms of the void agreements.

Griffiths $v$ Janse van Rensburg appears to have introduced a new factor to be considered in determining whether or not a disposition is made in the ordinary course of business. Although an objective approach investigation entails weighing all the facts of a case, Gorven AJA appears to place more emphasis on the nature of the relationship between the parties, and totally disregards the illegality of the business.

\section{Conclusion}

Although pyramid schemes are illegal and cannot be enforced between the parties to such an agreement, in order to give effect to the impeachable disposition provisions in the Insolvency Act, the illegality of the agreements is disregarded. This outcome was held in Janse van Rensburg $v$ Botha not to amount to the upholding of an illegal agreement, but to giving effect to the legal consequences that emanate from the illegal agreement and, in the main, to recovering assets of the insolvent estate for the benefit of creditors.

It is clear that the objective approach is still the approach to follow in determining whether a disposition made by a pyramid scheme was made 
in the ordinary course of business for the purposes of section 29 of the Act. In earlier cases, only the illegal gains made by the investor were set aside. This outcome was based on the dictum that a disposition can be made in the ordinary course of business only if it was a lawful disposition and the business was lawful. In Griffiths $v$ Janse van Rensburg, the most recent decision by the Supreme Court of Appeal, the court set aside the issue of both the illegal gains and the capital repayments. The court held that the focus should be on the nature of the relationship between the parties and not on the illegal nature of the business. This Supreme Court of Appeal case, however, created further uncertainty and inconsistency regarding which factors to consider or to which factors more weight must be given.

An investor who acted in good faith in participating in the scheme may rely on section 33 of the Act in the case of a claim by the trustee or liquidator in terms of sections 26, 29 and 30 to have the disposition set aside. Having shown good faith, however, is difficult to prove, and neither section 33 nor the courts have indicated the factors that show good faith and whether or not, if good faith is shown, the investor can keep both the capital repayments and the illegal gains. This uncertainty may give rise to further Supreme Court of Appeal cases in this regard.

\section{Bibliography}

\section{Literature}

Bertelsmann et al Mars

Bertelsmann E et al Mars: The Law of Insolvency in South Africa $9^{\text {th }}$ ed (Juta Cape Town 2008)

Meskin et al Insolvency Law

Meskin PM et al Insolvency Law and its Operation in Winding-up (LexisNexis Butterworths Durban Last updated October 2015)

Sharrock, Van der Linde and Smith Hockly's Insolvency Law

Sharrock J, Van der Linde K and Smith A Hockly's Insolvency Law $9^{\text {th }}$ ed (Juta Cape Town 2012)

Visser Unjustified Enrichment

Visser D Unjustified Enrichment (Juta Cape Town 2008)

Woker 2013 SA Merc LJ

Woker TA "If It Sounds Too Good to Be True It Probably Is: Pyramid Scheme and Other Related Frauds" 2013 SA Merc LJ 237-249 


\section{Case law}

Afrisure $v$ Watson 2008 ZASCA 89 (11 September 2008)

Amalgamated Banks of South Africa Bpk v De Goede 19974 SA 66 (SCA)

Cooper v Merchant Trade Finance Ltd 20003 SA 1009 (SCA)

Eliasov v Arenel (Pvt) Ltd 19793 SA 415 (R)

Estate Hunt $v$ De Villiers 1940 CPD 79

Estate Jager $v$ Whittaker 1944 AD 246

Estate Wege v Strauss 1932 AD 76

Fourie v Edeling 20054 All SA 393 (SCA)

First National Bank of Southern Africa Ltd v Perry 20013 SA 960 (SCA)

Gazit Properties v Botha 20122 SA 306 (SCA)

Griffiths v Janse van Rensburg 2015 ZASCA 158 (26 October 2015)

Gore v Shell South Africa (Pty) Ltd 20042 SA 521 (C)

Hendriks $v$ Swanepoel 19624 SA 338 (A)

Hill v Maria Christ 1927 SWA 50

Janse van Rensburg v Botha 2011 ZASCA 72 (25 May 2011)

Janse van Rensburg v Griffiths 20142 All SA 670 (ECP)

Klerck v Kaye 19893 SA 669 (C)

Louw v DMA Fishing Enterprises Pty Ltd 20022 SA 163 (SE)

Moodaley v King 2009 ZANCHC 52 (30 October 2009)

MP Finance Group CC (In Liquidation) v Commissioner, South African Revenue Service 20075 SA 521 (SCA)

Paredes-Tarazona v Cobalt Capital (Pty) Ltd 2012 ZAGPJHC 75 (23 April 2012)

Pretorius' Trustee v Van Blommenstein 19491 SA 267 (O)

Rousseau v Visser 19892 SA 289 (C)

Simon v Coetzee 20072 All SA 110 (T)

Venter v Volkskas Ltd 19733 SA 175 (T)

\section{Legislation}

Banks Act 94 of 1990 
Consumer Protection Act 68 of 2008

Insolvency Act 24 of 1936

National Credit Act 34 of 2005

\section{List of Abbreviations}

CPA

SA Merc LJ
Consumer Protection Act 68 of 2008

South African Mercantile Law Journal 